\title{
Reproductive Performance and Wastage in Large Ruminant (Cattle) in Ethiopia-Review
}

\author{
Gezu Tadesse* and Azage Tegegne \\ ${ }^{1}$ Haramaya University, School of Animal and Range Science, Ethiopia \\ ${ }^{2}$ International Livestock Research Institute, Ethiopia
}

Submission: October 13, 2018; Published: November 01, 2018

*Corresponding author: Gezu Tadesse, Haramaya University, School of Animal and Range Science, Ethiopia

\begin{abstract}
The objective of this paper is to review the reproductive performance and wastage in large ruminants (cow) in Ethiopia. Though the number of female cattle in Ethiopia is high (55.38\% (32.0 million)), the production and reproductive performance (crucial factor) needs to be improved. For modern dairy industry, reproductive performance is the most important to determine the efficiency of dairy cattle. Even though, age at first service, age at first calving, day's open, calving interval and number of services per conception are the most factors; management and cowlevel factors also determine the reproductive performance of dairy cow. The indigenous cattle of age at first service, age at first calving and calving interval is $34.4 \pm 2.28$ to $56.16 \pm 7.56$ months, 33.9 to $57.69 \pm 1.11$ months and $13.59 \pm 0.26$ to 26.04 months, respectively. There is wastage of reproductive due to environmental, genetic, disease and management factors. So, to improve the productivity and production of native breeds, detail understanding of current performance, identifying challenges and opportunities with the causal factors is very important.
\end{abstract}

Keywords: Indigenous cattle; Reproductive performance; Wastage

Abbreviations: DMY: Daily Milk Yield; AFS: Age at First Service; AFC: Age at First Calving; CI: Calving Interval; NSC: Number of Services per Conception; DO: Days Open; BCS: Body Condition Score; RFM: Retained Fetal Membrane

\section{Introduction}

Ethiopia holds the largest livestock population in Africa. The estimated cattle population in Ethiopia is about 57.83 million, 28.04 million sheep, 28.61 million goats, 1.23 million camel and 60.51 million poultry. Out of 57.83 million cattle the female cattle constitute about $55.38 \%$ (32.0 million) and the remaining $44.55 \%$ (25.8 million) are male cattle. From the total cattle in the country $98.59 \%$ (57.01million) are local breeds and remaining are hybrid and exotic breeds that accounted for about $1.19 \%$ $(706,793)$ and $0.14 \%(109,733)$, respectively. Smallholder dairy farms in Ethiopia particularly in regional and zonal cities are alarmingly increasing because of high demand of milk and milk product from resident. However, the existing farming system which holds maximum of 10 or 15 cows per individual is not satisfactory to fulfill the demand. In addition, farming system has a major problem with regards to feed source, feed supply and the amount given per animal below the minimum standard, which entails in reduction in production and reproduction in the farms [1].

Productive and reproductive traits are crucial factors determining the profitability of dairy production [2], and poor reproductive performance, exposed as prolonged calving intervals, can result in reduced milk yield and increased culling rates and replacement cost [3]. The most common reproductive performance is age at first service, age at first calving, day's open, calving interval and number of services per conception $[1,4]$. In addition, major reproductive performance factors encompass both management factors (such as methods of husbandry, feeding, estrus detection, semen handling and transition cow management) and cow-level factors (such as age, BCS, post parturient problem, disease, milk yield, and genetics) [5]. Hammoud [6] also proposed, maximum rates of breeding efficiency in dairy cattle are attained through regular calving of one viable offspring per breeding cow in the herd in a year.

Reproductive health problems cause considerable economic loss to the dairy industry [7] due to slower uterine involution, prolonged inter conception and calving interval, negative effect on fertility, drop in milk production and early depreciation of potentially useful cows [8]. Reproductive wastage is normally considered to cover all losses from mating to the first breeding of the offspring or death of a foetus, calf or cow between confirmed pregnancy diagnosis and weaning, and calculated as a percentage of pregnant cows. Reproductive wastage is caused by environmental, genetic, disease and management factors which operate with different severities and in different combinations. These factors interfere with ovulation, fertilization or 
implantation and during gestation and parturition [9]. Thus, reproductive disorders are one of the most important problems that affect the production and productivity of dairy cows [10]. Therefore, the objective of this review is documenting the reproductive performance and wastage in large ruminants (cow) in Ethiopia.

\section{Milk Yield and Lactation Length Performance of Ethi- opian Cows}

The main parameter that is used to gauge the efficiency of production in dairy farm is milk. According to CSA reported, the average milk yield per cow per day is about 1.37 liters. Milk production in Ethiopian zebu produces an average range of 2-4 liters with minimum of 1 liters and maximum of 6 liters [1]. The average daily milk yield (DMY) performances of indigenous cows in PLWs was 1.85 litres/day and ranged from 1.24 litres in rural lowland agro-pastoral system of Mieso to 2.31 litres in rural highland dairy production system of Fogera [11]. In addition, the mean daily milk yield/liters for local cow in western Oromiya is $2.2 \pm 0.6$ [12]. According to Mustefa \& Adebabay [13] stated, the yield of milk for local cows is $1.96 \pm 0.8193$ and 1.82 liters/day in Wolmera areas and Bure district, respectively.

There is a variation in daily milk yield performances of cattle (local) due to agro-ecology effect. For example, the value of average daily milk yield was higher in mid land $(2.127 \pm 0.094)$ than low land $(1.861 \pm 0.084)$ [14]. Also, the average milk yields for the different stages of lactation in Mecha and Bahir Dar Zuria Districts was 2.0, 1.2 and 0.6 litres for the first, second and third lactations, respectively with an overall average milk yield of 1.2 litres for local cows [15]. Moreover, the average milk yield of local cows per day are $2.73 \pm 0.82,2.01 \pm 0.73$ and $0.85 \pm 0.35$ litres for the first, second and third stage of lactations, respectively with an overall average of $1.86 \pm 0.63$ litres per day [16]. In general, the lower average daily milk yield per cow can be attributed by poor management practice (housing, feeding system and feed nutritional value), stage of lactation and poor genetic potential of the sample population and disease (mastitis which contribute to the low milk production) prevalence.

Lactation length is the time, through which a cow continues giving milk in one parturition. The average lactation period per cow at country level is estimated to be about six months. The average lactation length in North Showa zone showed for local breeds is 273.9 days [17]. Beriso [18] also reported, the lactation length in Aleta Chukko District was $9.93 \pm 0.2$ months. Kedija \& Adebabay [19] stated, the average lactation length of local cows was 7.29 months at Meiso 9.8 months at Bure District, respectively.

The overall average lactation length $324.06 \pm 15.09$ days (10.802 \pm 0.503 months) and it varies between agro-ecologies, in midland areas the local dairy cattle can be milking for longer period $(11.875 \pm 0.748)$ than lowland areas $(9.82 \pm 0.66$ years). This might be related with, in midland areas by nature there is exceptional longer rainfall period besides, normal rainfall as result there would be forage availability for milking cows for some extent. Tadesse [20] noted that lactation milk yield is influenced by period of calving and parity number, but no by season of calving. Genotype has own effect on yield performance for lactation milk yield, when variation among genotypes in milk production potential is attributed to genetic potential of each genotypes and poor management (housing, feeding system and feed nutritional value) and disease (mastitis) resistance [21].

\section{Reproductive Performance of Ethiopian Dairy Cows}

Reproductive performance is one of the most important concerns of the modern dairy industry worldwide, and it is characteristic of outstanding importance in dairy cattle business and often a major determinant of biological and economic efficiency of livestock production in tropics [22]. The reproductive performance of the breeding female is probably the single most important factor that is a prerequisite for sustainable dairy production system and influencing the productivity $[23,24]$. The causes of decreasing fertility in dairy cattle are multifactorial origin, and the relevance of different factors varies depending on the geographical areas and the herd [25]. Many factors such as management, nutrition, and genetics are among the reasons for deterioration of reproductive performance [26]. There is a relatively better reproductive performance of dairy cows at Bishoftu because of better feed availability, better AI services in bigger towns, and educational status and farming experience of dairy owners [27].

\section{Age at first service (AFS)}

Age at first service (AFS) is the age at which heifers attain body condition and sexual maturity for accepting service for the first time. Age at first service in Ethiopia highland Zebu and Horro cattle were 53 and 55 months, respectively. Sisay \& Assemu [28] also reported for Horro and Fogera cows are $46.79 \pm 1.03$ and $42.24 \pm 0.05$ months, respectively. In addition, the mean age at first service of local heifer reported by Adebabay is 42.48 months in Bure district. AFS in selected Gojam zone varies for different production system reported by Melku are $56.16 \pm 7.56,45.00 \pm 2.28$ and $39.00 \pm 5.40$ in rural, peri-urban and urban production system, respectively; because there is good management practice (feeding health care and housing sys-tem) in urban production system. The average age at first service for Ogaden heifers at Haramaya University is $34.4 \pm 2.28$ months, with minimum and maximum values of 22.6 and 51.5 months, respectively. However, $26 \%$ of Ogaden heifers the age at first service is below 24 months. Heifers are considered ready for mating from about 24 months of age or about $200 \mathrm{~kg}$ body weight [29].

The average AFS of local heifers was 42.48 months Adebabay and Beriso reported, $51.24 \pm 0.55$ in Aleta Chukko District. AFS is influenced by genotype, nutrition and other environmental factors. First calving marks, the beginning of a cow's productive life and influences both the productive and reproductive life of the female, directly through its effect on her lifetime calf crop 
and milk production and indirectly through its influence on the cost invested for up-bringing. Also, a substantial delay in the attainment of sexual maturity may lead a serious economic loss, due to additional, non-lactating, unproductive period of the cow over several months [30] (Table 1).

Table 1: Age of first calving for different Ethiopian cattle.

\begin{tabular}{|c|c|c|}
\hline Place/local breed & AFC & Auther/s or source \\
\hline Bahir Dar & 4.76 years & Asaminew [15] \\
\hline Mieso District & $52.49 \pm 0.91$ months & Kedija [19] \\
\hline Ogaden cattle at HU & $49.2 \pm 4.43$ months & Getinet [29] \\
\hline Fogera cattle & $50.8 \pm 0.36$ months & Melaku [39] \\
\hline Metekel ranch & $52.43 \pm 0.17$ months & Almaz [38] \\
\hline Tigray (pri-urban) & $3.63 \pm 0.69$ years & Gebrekidan [24] \\
\hline Chacha district & $47.16 \pm 8.7$ months & $\begin{array}{c}\text { Mulugeta \& } \\
\text { Belayeneh [17] }\end{array}$ \\
\hline Horro & $57.69 \pm 1.11$ months & Sisay [21] \\
\hline Fogera cattle & $51.4 \pm 0.05$ months & Assemu [34] \\
\hline $\begin{array}{c}\text { Fogera cattle at } \\
\text { Metekel Ranch }\end{array}$ & $55.44 \pm 6.72$ months & Melku [16] \\
\hline Arsi zebu & 33.9 months & Solomon [1] \\
\hline Wolayita Zone & $3.926 \pm 0.090$ years & Zeru [14] \\
\hline
\end{tabular}

\section{Age at first calving (AFC)}

Age at first calving is the age at which heifers calve for the first time. The beginning of productive life the heifer is called age at first calving. The AFC several studies carried out for local cows are varying. The desirable age at first calving in local breeds is 3 years, even if the recommended heifers calve between 23 and 25 months of age, which is considered as optimum that increase profitability of the dairy business. AFC is one of the important factors contributing to economic return and is determined partially by farmer policy. AFC is affected by different factors like breed, nutritional status and management differences of dairy cows. For example, AFC in selected Gojam zone is higher in urban $(66.48 \pm 7.68)$ than peri-urban $(49.92 \pm 7.08)$ and urban $(49.80 \pm 5.40)$ production system because of poor management. First calving marks, the beginning of a cow's productive life and influences both the productive and reproductive life of the female, directly through its effect on her lifetime calf crop and milk production and indirectly through its influence on the cost invested for upbringing.

Under controlled breeding, heifers are usually mated when they are mature enough to withstand the stress of parturition and lactation. This increases the likelihood of early conception after parturition. In traditional production systems, however, breeding is often uncontrolled, and heifers are bred at the first opportunity. This frequently results in longer subsequent calving intervals. Researchers have indicated in Ethiopia that of highland zebu had 53 months [1]. In general, earlier calving increases lifetime productivity of cows. AFC influences both the reproductive and productive life of the female directly through its effect on her life time, calf crop and milk production and indirectly upon cost invested for her upbringing and the magnitude of genetic progress. Prolonged age at first calving will have high production in the first lactation but the life time production will be decreased due to less no of calving. If the age at first calving is below optimum, the calves born are weak, difficulty in calving and less milk production in first lactation.

\section{Calving Interval (CI)}

CI is the gap between two successive calving or a time elapsed between two consecutive successive parturitions, and ideally should be 12 to 13 months. CI probably the best index of a cattle herd's reproductive Efficiency. The calving interval can be divided into three periods: gestation, postpartum anestrus (from calving to first estrus) and service period (first postpartum estrus to conception) (Table 2).

Table 2: Calving interval for different Ethiopian cattle.

\begin{tabular}{|c|c|c|}
\hline Breed/place & CI & Source \\
\hline Fogera district & 20.04 months & Addisu \\
\hline Mieso district & $16.01 \pm 0.49$ months & Kedija [19] \\
\hline North Gondar & $17.8 \pm 2.23$ months & Tewodros [30] \\
\hline Ogaden cattle at $\mathrm{HU}$ & $492.9 \pm 13.23$ days $/ 16$ & Getnet [29] \\
\hline Fogera cattle & 19.6 months & Melaku [39] \\
\hline Bure districts & 26.04 months & Adebabay [13] \\
\hline $\begin{array}{c}\text { Fogera cattle } \\
\text { (Metekel Ranch) }\end{array}$ & 19.4 months & Almaz [38] \\
\hline $\begin{array}{l}\text { Local peri urban area } \\
\text { of Tigray }\end{array}$ & 23.16 months & Gebrekidan [24] \\
\hline $\begin{array}{l}\text { Boran (Tatesa } \\
\text { breeding center) }\end{array}$ & 622.6 days $/ 20.8 \mathrm{~m}$ & Yifat [67] \\
\hline $\begin{array}{l}\text { Angolellantera } \\
\text { district }\end{array}$ & $24.94 \pm 4.1$ months & $\begin{array}{c}\text { Mulugeta \& Belayneh } \\
{[17]}\end{array}$ \\
\hline Around Mekelle & $\begin{array}{l}453.6 \pm 88.3 \\
\text { days } / 15 \mathrm{~m}\end{array}$ & Niraj [24] \\
\hline Aleta Chukko & $19.93 \pm 0.18$ months & Beriso [18] \\
\hline Horro cows & $13.59 \pm 0.26$ months & Sisay [21] \\
\hline Fogera cattle & $21.18 \pm 0.7$ month & Assemu [34] \\
\hline $\begin{array}{l}\text { Fogera cattle at } \\
\text { Metekel Ranch }\end{array}$ & $22.15 \pm 4.22$ months & Melku [39] \\
\hline $\begin{array}{l}\text { Arsi zebu and local } \\
\text { cows at DB }\end{array}$ & 14.2 and 45 months & Solomon [1] \\
\hline Wolayita Zone & $\begin{array}{l}19.913 \pm 0.832 \\
\text { months }\end{array}$ & Zeru [14] \\
\hline
\end{tabular}

Calving interval (CI) is one of the major components of reproductive performance that influences livestock production system [31]. Tadesse noted that longer CI may mainly be attributed to the result of longer CFSI and DO obtained which could be related to environmental factors, mismanagement practices like poor housing, poor nutrition or failure to detect heat by the farmer. For example, CI in selected Gojam zone is 
higher in urban $(26.72 \pm 6.55)$ than peri-urban $(20.52 \pm 3.78)$ and urban $(19.20 \pm 2.33)$ production system because of poor management. Though, calving interval is the best indicator of reproductive efficiency, extended calving interval is one of the major problems that reduce lifetime productivity of dairy herds [32]. Poor reproductive performance, manifested as prolonged calving intervals, can result in reduced milk yield and increased culling rates and replacement cost.

\section{Number of services per conception (NSC)}

The number of services per conception (NSC) depends largely on the breeding system used. It is higher under uncontrolled natural breeding and low where hand-mating or artificial insemination is used. The average number of services per conception of local cows was 1.59. Number of services per conception reported around Mekelle, Bako research center, the overall least squares means in the Maksegnit town [33] and Fogera cows [34] are $2.1 \pm 0.1,1.34 \pm 0.112 .0 \pm 0.65$ and $1.42 \pm 0.05$ respectively. Also, the number of service per conception reported by Melku for rural peri-urban and urban production system are $2.51 \pm 0.73,1.37 \pm 0.71$ and $1.13 \pm 0.40$, respectively.

NSC values greater than 2.0 should be regarded as poor [35] natural service conception has 1.18 whereas artificial insemination users (1.5 up to 2.3). This might indicate that there are problems in using AI methods due to various reasons, of these factors feed availability, time of insemination and heat detection plays a major role. Higher NSC results from either failure to conceive at a given service and/or failure to maintain pregnancy, thus requiring repeated services. Habtamu \& Hammoud [36] also reported that year of calving and parity number exerted a significant effect on conception rate to first service.

\section{Days Open (DO)}

Days open refers the interval from calving to conception (i.e. the number of days between parturition and the insemination that resulted in a pregnancy). According to Niraj and Sisay stated, the DO is 185.8 \pm 51.2 (Mekelle) and $88.13 \pm 2.03$ (Horro) days for dairy cows, respectively. Due to good management practice in urban production system $(233.40 \pm 57.60)$ DO is good than rural $(346.80 \pm 33.60)$ and peri-urban $(303.60 \pm 38.40)$. In addition, the overall least squares mean for DO in indigenous dairy cows in Maksegnit town is $86.5 \pm 4.5$ estimated to be days [33]. Year of calving has significant effect on DO but season of calving did not affected DO. However, there is significant effect of parity number, summer season and season of calving has significant effect on DO. A herd average of less than 85 open days indicates that cows are being breed early, 85 to 115 days considered as optimum for dairy herd, 116 to 130 indicate slight problem, 131 to 145 moderate problems, while more than 145 open days considered as sever reproductive problem in the dairy herd.

\section{Birth and Weaning Weight}

The overall mean birth weight of Fogera cattle breed calves is $21.4 \pm 0.09 \mathrm{~kg}$, but the mean birth weight of Fogera calves is lower
$(20.7 \pm 0.11 \mathrm{~kg})$ reported by Addisu. Birth weight affected by sex of calf, season of birth and year of birth while parity of dam exerted non-significant effect. Male calves are heavier than their female counterparts $(21.3 \pm 0.08 \mathrm{~kg}$ vs. $20.5 \pm 0.08 \mathrm{~kg})$. Moreover, the overall least squares mean of birth weight is $21.50 \pm 0.29 \mathrm{~kg}$, with $20.98 \pm 0.31 \mathrm{~kg}$ for females and $22.03 \pm 0.33 \mathrm{~kg}$ for males. Calves born during the dry season is heavier than those born during the short rainy season. This might be because dams calved in the dry season would have better nutrition during the previous season therefore be in a better body condition during calving. In general, birth weight declines as year advances might be because the deterioration of the grazing lands due to over grazing and variability in birth weight across years implies inconsistency of management level of the farm and variability of natural pasture between years. Researchers reported that year (season) of birth a significant effect on birth weight of calves [37].

The overall mean of weaning weight at eight months (mean weaning age of calves at ALRC) of Fogera calves are $102.2 \pm 0.77 \mathrm{~kg}$ Assemu and Aynalem reported 79.0 $\pm 1.51 \mathrm{~kg}$ for Ethiopian Boran breed. But Almaz [38] reported for Fogera cattle breed calves at ALRC is lower $(88.6 \pm 0.33 \mathrm{~kg}$ ) compared to than Assemu. Getinet also reported for Ogaden breed at six months of age is $91.7 \pm 1.67 \mathrm{~kg}$, this is might be due to the weaning age and production objective difference of the breeds. Weaning weight of Fogera calves is $88.6 \pm 1.3 \mathrm{~kg}$. The least squares means of live weights of calves at weaning and 9 months are $91.65 \pm 1.67 \mathrm{~kg}$ and $111.1 \pm 2.16 \mathrm{~kg}$, respectively, with $95.42 \pm 1.92 \mathrm{~kg}$ and $116.64 \pm 2.49 \mathrm{~kg}$ for males and $87.88 \pm 1.95 \mathrm{~kg}$ and $105.50 \pm 2.37 \mathrm{~kg}$ for females and the overall least square means weight at 24 and 30 months of ages are $200.7 \pm 3.43$, and $234.79 \pm 3.67 \mathrm{~kg}$, respectively, which meet the minimum weight for the age of export beef animals. Calves born during wet season has additional weight over calves born during dry season.

Calves born in the short rainy season were heavier than those born in the main rainy season $(90.2 \mathrm{~kg}$ vs. $86.7 \mathrm{~kg})$, which might be due to the fact that dams calved during the short rainy season would get better available forage in the main rainy season thus produce better milk for the calves while those calved in the main rainy season immediately gets in the dry season. Less milk production by younger and older cows can bring a calf with lower weaning weight. This might be due to the availability of optional feed resource during wet season, which are palatable and digestible for the calves. Season has significant effect on weaning weight of calves for Fogera cattle breed [39]. The trend of birth weight and weaning weight of Fogera cattle breed at the research center had shown a considerable decrement across the advancement of year. The decreasing trend might be due to deterioration of the production environments (feed quality and seasonality; and disease prevalence), lack of care and facility improvement for the center, unavailability of continuous concentrate feed supply for dams and poor recording system. Additionally, the shift of the ranch to the research center without any facility and feeding strategy, increasing the cattle population 
trend and invasion of the grazing land by unpalatable weeds, and absence of strategic selection mechanism favors for the declining trend.

\section{Factors Affecting Reproductive and Productive Per- formance of Dairy Cattle}

Factors affecting reproductive performance are associated to either to the management factors (such as methods of husbandry, feeding, estrus detection, semen handling and transition cow management) or to the cow factors (such as age, body condition score (BCS), post-parturient problem, disease events, milk yield, and genetics). The performance of animals depends not only on their genetic merits, but also on other factors such as nutrition, management, health, and environment. Genetic factors are likely to explain only a small proportion of variation in fertility within a population of cows and suggests the strong influence of environmental factors such as management decisions on the reproductive efficiency of dairy cows. There is strong evidence that reproductive performance has a negative relationship with milk production.

Report on delay on postpartum resumption of ovarian activity due to longer CFSI, poor expression of estrus by the cow, failure to detect estrus by herd attendant or both are also the major causes for poor reproduction performance. Absence of heat detection aids, improper AI technique, shortage of experienced inseminators, poor management (feeding, housing, and heat detection) of dairy cows and heifers and early embryonic mortality are the implicated factors on reproductive performance and poor AI efficiency of smallholder dairy cows and heifers [40]. The effect of year of calving and birth on reproductive performance of dairy cows could be attributed change in climatic condition during different seasons.

Nutrition has the major limiting impact on productive and reproductive performance in all animals. It also plays a major role on enhancing reproductive efficiency of dairy cows. Energy and protein are the major nutrients required in the greatest amounts and should be in the topmost priority to optimize reproduction in dairy cattle; but also, minerals and vitamins can't be neglected and must be optimum in the diet [41]. Hammoud stated, changes in feeding systems which occurred from year to another as well as to differences between years in the quantity and quality of forage availability have a significant effect in year of calving or birth on reproductive performance of dairy cows. Proper heat detection, feeding and postpartum reproduction management may reduce NSC, and hence there is a possibility of reduction in day's open and calving interval. The incidence dystocia retained foetal membranes clinical and subclinical metabolic disease, mastitis and abnormal displacement can have a significant impact on resumption of ovulation in dairy herds through their effects on uterine involution. Changes in management and environmental condition from year to another year delays age at first service and calving.

\section{Reproductive Wastage and Reproductive Health Prob-} lem

\section{Reproductive Wastage}

Reproductive wastage is normally considered to cover all losses from mating to the first breeding of the offspring or death of a foetus, calf or cow between confirmed pregnancy diagnosis and weaning, and calculated as a percentage of pregnant cows. Reproductive wastage is caused by environmental, genetic, disease and management factors which operate with different severities and in different combinations. These factors interfere with ovulation, fertilization or implantation and during gestation and parturition. According to Amuanmuta reported for Fogera cattle, the overall mortality rate of $4.9 \pm 1.3,6.8 \pm 1.4,7.3 \pm 1.7$ and $10.1 \pm 2.0$ at the end of 30 days (neonatal period) 180, 240 (pre-weaning) and 360 days, respectively. Of the 640 total female cattle reproductive tracts examined in Sululta slaughterhouse, $28.9 \%$ uterus are found pregnant, $66.6 \%$ (426) are cyclic ovarian activities. Of the cycling cows, $7.5 \%$ are pregnants. $65.4 \%$ of the fetuses are at early ( $<3$ months), 30.3\% are mid (3-6 months) and the rest $4.3 \%$ are at late ( 6 months) ages of pregnancies [42]. Also, the total number of pregnant cows slaughtered during the Hawassa municipality abattoir and Tula slaughter house is 92. Of the total pregnancies, $45.65 \%$ are found with early (first trimester), $30.43 \%$ are mid (second trimesters) and $23.91 \%$ are late stages (third trimesters). It is also found that the right ovaries have the highest physiological activities than the left ovaries and their percentage are $65.45 \%$ and $34.55 \%$ on the right and left, respectively [43].

\section{Reproductive health problem}

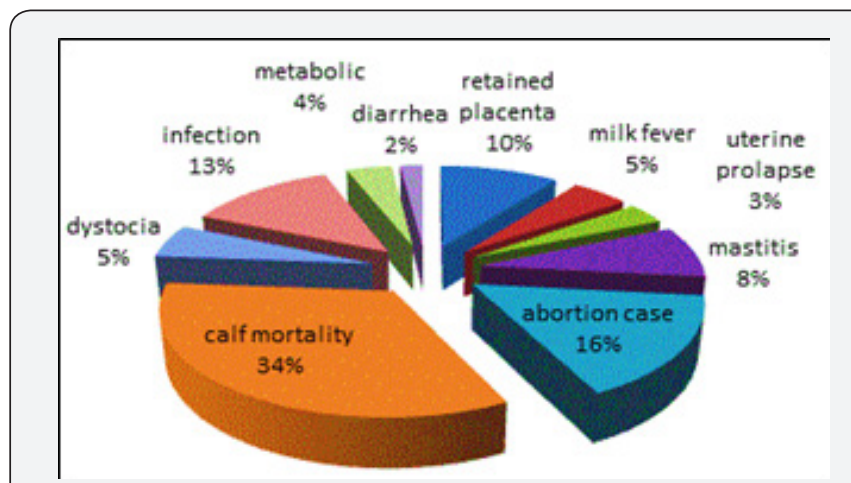

Figure 1: Major health problems reported in Hawassa and Debre brihan.

The effects of the disease on reproductive tract causing retained fetal membrane that usually leads to uterine infection and hence poor conception rate. The number of services per conception increases when cattle are repeatedly experience abortion, retained fetal membrane, dystocia and other reproductive health problems [44]. High prevalence of reproductive health problems is mastitis, abortion, repeat breeder, anestrus and RFM are the most prevalent problems of dairy cows in Borena zone [45]. In different parts of Ethiopia 
indicated that $26.5 \%$ of cows examined has at least one of reproductive problems in and around Bedelle south west Ethiopia [46], and retrospective analysis of clinical data in central Ethiopia showed $44.3 \%$ of the cows has major prepartum and postpartum reproductive problems [47]. According to Bahlibi [48] reported, $51(19.3 \%)$ affected with the major reproductive problems, of which repeat breeding (9.1\%), anoestrus (4.2\%) and abortion (3.8\%) are the major reproductive problems in selected Tigray region. Also, the occurrence of reproductive problems in the same study areas are $26.7 \%$ repeat breeding, $20 \%$ anoestrus, $5.8 \%$ retained fetal membranes, 5.8\% uterine prolapsed, $28.3 \%$ abortion and $26.7 \%$ testicular swelling (Figure 1). Gashaw [49] and Dawit and Ahmed also reported the prevalence of $33.59 \%$ and $40.25 \%$ of reproductive health problems of cows in Jimma town, south-west Ethiopia and Kombolcha, north-east Ethiopia, respectively.

Reproductive problems like retained placenta, uterine prolapse, milk fever, calf mortality, still birth, abortion, infection, dystocia and others. Calf mortality (34\%) and abortion case $(16 \%)$ receive high proportion among the reported problems followed by infectious diseases like blackleg, foot and mouth, foot abscess. Calves within 1-3 months of age showed relatively high proportion of mortality (42.3\%), less than month (30.9\%) and above 3 months (26.8\%). Abebaw [50] reported, from the total of 396 dairy cows in-Jimma town, 33.59\% (133) affected either with one or more reproductive health problems. Retained Fetal Membrane (RFM), mixed problems, dystocia and endometritis are found to be the major reproductive health problem. According to calf morbidity and mortality have short-term and longterm detrimental effects on performance of a dairy farm [51]. Moreover, according to Adane [52] in Hossana and peri-urban farms, repeat breeder, anoestrus, Retained Fetal membrane (RFM), and dystocia are the major reproductive health problems containing $13.08 \%, 12.06 \%, 7.18 \%$ and $5.9 \%$ prevalence rate respectively and other reproductive health problems observed with lower prevalence include vaginal prolapsed, abortion, mixed and uterine prolapsed having 3.44\%, 2.56\%, 1.03\%, and $0.76 \%$ respectively.

Females mortality peaked at the end of the big rainy season (August-September) animals, 37\%), in the opposite of bulls which peaked during the end of the dry season between April and June ( 1 out of 22 animals, $45 \%$ ). Mortality peaked in calves aged 5 to 7 months (45\%) and the main mortality peak is during the dry season (April-June) $45 \%$ followed by a second peak in September at the end of the dry season $(15 \%)$ and a third in December [53]. Higher morbidity (77.8\%) and mortality $(22.2$ $\%$,) is registered in calves below three months of age compared to $50 \%$ and $16.7 \%$, respectively in calves above three months of age [54]. Among the diarrheic dairy calves, $68.4 \%$ affected at the age of less than two months, followed by $26.3 \%$ at the age of 2-4 months, and $5.3 \%$ at the age of 4-6 months. Delayed first colostrum feeding led to increased morbidity and mortality ( $80.0 \%$ and $40.0 \%$, respectively) compared to early colostrum consumption (60.0 \% and $10.0 \%$, respectively. The major reproductive health problems for Borana are mastitis $(21.3 \%)$, abortion $(12.2 \%)$, repeat breeder $(10.3 \%)$, anestrus $(10.3 \%)$ and retained fetal membrane (RFM; 7.6\%; $n=31 / 409$ ). The rate of abortion increased with the increase in the stage of gestation.

\section{Reproductive Performance Improvement in Dairy cattle}

Improving reproductive performance of dairy cows requires understanding of current performance, identifying challenges and opportunities with the causal factors, and subsequently creating sustainable options for overcoming the problems. In Ethiopia, there are extreme variations in livestock production systems, climate and access to services; success in breed improvement depends on flexibility. Therefore, breeding programs should be somehow flexible to be responsive to variable scenarios for future needs of the programs. For example, demands for the product type and quality can change with time and hence the program must respond to such changes. Management practices affect pregnancy success and reproductive performance of smallholder dairy cows. Apart from the conventional methods of evaluating reproductive performance, the introduction of evaluation parameters such as submission to service at the right time post-partum, pregnancy by day 200 and non-pregnancy by day 300 provide which are directly influenced by the management practices provide a useful evaluation alternative.

\section{Effect of Climate Change on Large Ruminant Produc- tion and Productivity}

Climate change is a long-term shift in the statistics of the weather such as temperature, radiation, wind and rainfall characteristics of a region. Climate change has profound effect on livestock. The anticipated rise in temperature due to climate change is likely to aggravate the heat stress in livestock, adversely affecting their productive and reproductive performance. The predicted negative impact of climate change on agriculture would also adversely affect livestock production by aggravating the feed and fodder shortages. The livestock sector which will be a sufferer of climate change is itself a large source of methane emissions, an important greenhouse gas. The paper mainly reviews the contribution of livestock to climate change and impacts of climate change on livestock milk production, reproduction, livestock diseases and mitigation strategies to counteract climate change effects [55]. Livestock systems in developing countries are characterized by rapid change, driven by factors such as population growth, increases in the demand for livestock products as incomes rise, and urbanization [56]. Climate related hazards in Ethiopia include drought, floods, heavy rains, strong winds, frost, heat waves (high temperatures) and lightning [57]. Rainfall variability greatly influenced herd dynamics in terms of herd die-offs and lower birth rates, which also considerably affected milk production for household consumption [58]. 
Climate change and variability can severely constrain the productivity of pastoral herds by reducing water availability, forage production and quality, and hence the carrying capacity of rangelands. The risk of heavy livestock losses suffered during recurrent severe droughts associated with climate change and variability presents one of the most serious threats to pastoral livestock keepers [59]. On average, global temperatures will likely increase worldwide by 0.2 degrees per decade. There will be fluctuation in precipitation, increase in droughts and floods [60]. Livestock production systems may be affected in various ways, and changes in productivity are inevitable [61]. climate change affects the sector directly through temperature increases and shifts in rainfall amounts and patterns and through ecosystem changes, changes in crop yield, quality, and types, alter the distribution of animal diseases, and increased competition for resources indirectly. In Borana, Ethiopia showed that rainfall variability greatly influenced herd dynamics under the communal and ranch management in terms of herd die-offs and lower birth rates, which also considerably affected milk production for household consumption.

Droughts of the 1980s and 1990s caused 49\% herd losses under the communal land use, while $57 \%$ of the cattle mortality under ranch management was attributed to droughts of the 1990 [62-65]. Cattle herd dynamics is strongly determined by rainfall variability in southern Ethiopia. Hygienic condition, feeding, housing and health management should be improved to minimize the occurrence of these problems and associated economic losses in the dairy farms. The reproductive problems according to their relative importance in and around Bedelle were Metritis 51 (16.9\%), abortion 42 (13.9\%), Retained Fetal Membrane (RFM) 26 (8.6\%), dystocia 20 (6.6\%), repeat breeding $9(3 \%)$, anoestrous $5(1.7 \%)$, prolapse (vaginal and uterine) 3 (1\%) and $2(0.65 \%)$, respectively $[66,67]$.

\section{Conclusion and Recommendation}

\section{Conclusion}

98.59\% (57.01million) of country cattle are local breeds and remaining are hybrid $(1.19 \%)$ and exotic $(0.14 \%)$ breed. Even though, Ethiopia has a huge livestock from the Africa, because of several problem like feed source shortage, high cost of concentrate feed, genetic potential, policy disease prevalence and lack of infrastructure, the productivity is too low. Reproductive performance of the breeding female is the single most important factor that is a prerequisite for sustainable dairy production system and influencing the productivity. In dairy sector, age at first service, age at first calving, calving interval, day's open, and number of services per conception are a crucial factor and influenced by management. The indigenous cattle of age at first service, age at first calving and calving interval is $34.4 \pm 2.28$ to $56.16 \pm 7.56$ months, 33.9 to $57.69 \pm 1.11$ months and $13.59 \pm 0.26$ to 26.04 months, respectively. There is wastage of reproductive due to environmental, genetic, disease and management factors. So, to improve the productivity and production of native breeds, detail understanding of current performance, identifying challenges and opportunities with the causal factors is important.

\section{Recommendation}

a. Should be improve genetic potential of native breeds though selection or breeding.

b. Awareness creation training for producers on heat detection, feeding and feed ration formulation, housing, record keeping and health care.

c. Creating linkage with Universities, Research Institutes Center, extension service, dairy cooperatives and NGOs for training, technology adoption transfer and dissemination.

d. Should be improve hygienic of dairy house and control those reproductive disease or economic importance disease particularly mastitis.

\section{References}

1. Solomon Mekuria (2016) Smallholder dairy farm management in Ethiopia: Status in Hawassa and Debrebrihan Cities. J Veterinar Sci Technol 7: 306.

2. Fikirie Lobago, Merga Bekana H, Gustafsson, Kindahl H (2007) Longitudinal observation on reproductive and lactation performances of smallholder crossbred dairy cattle in Fitche, Oromia region, central Ethiopia, Tropical Animal Health and Production 39: 395-403.

3. Sewalem, A, Miglior F, Kistemaker GJ, Sullivan P, Van Doormaal B] (2008) Relationship between reproduction traits and functional longevity in Canadian dairy cattle. J Dairy Sci 91: 1660-1668.

4. Zewdie wondatir (2010) Livestock production systems in relation with feed availability in the highlands and central Rift Valley, M.Sc. thesis submitted to the School of Animal and Range Sciences. School of Graduate Studies Haramaya University, Ethiopia.

5. Hudson CD, Bradley AJ, Breen JE, Green MJ (2012) Associations between udder health and reproductive performance in United Kingdom dairy cows. Journal of Dairy Science 95: 3683-3697.

6. Hammoud MH, El-Zarkouny SZ, Oudah EZM (2010) Effect of sire, age at first calving, season and year of calving and parity on reproductive performance of Friesian cows under semiarid conditions in Egypt. Archiva Zootechnica 13(1): 60-82.

7. Dawit Tesfaye, Ahmed Shamble (2013) Reproductive health problems of cows under different management systems in Kombolcha, Northeast Ethiopia. Advances in Biological Research 7: 104-108.

8. Benti AD, Zewdie W (2014) Major reproductive health problems of indigenous Borena cows in Ethiopia. Journal of Advanced Veterinary and Animal Research 1(4): 182-188.

9. Amuamuta A, Asseeged B, Goshu G (2006) Mortality analysis of Fogera calves and their Friesian crosses in Andassa Cattle Breeding and Improvement ranch, North West Ethiopia. Rev Med Vet 157: 525-529.

10. Hunduma Dinka (2013) Major reproductive disorders of dairy cows in and around Asella town, Central Ethiopia. Journal of Veterinary Medicine and Animal Health 5(4): 113-117.

11. Azage Tegegne, Berhanu Gebremedhin, Dirk Hoekstra, Berhanu Belay, Yoseph Mekasha (2013) Smallholder dairy production and marketing systems in Ethiopia: IPMS experiences and opportunities for marketoriented development. Ethiopia.

12. Ulfina Galmessa, Jiregna Dessalegn, Alganesh Tola, Prasad S, Mulugeta Kebede (2013) Dairy Production Potential and Challenges in Western 
Oromia Milk Value Chain, Oromia, Ethiopia. Journal of Agriculture and Sustainability. 2(1): 10-13.

13. Adebabay Kebede (2009) Characterization of milk production systems, marketing and on-farm evaluation of the effect of feed supplementation on milk yield and milk composition of cows at Bure District. MSc Thesis, Bahir Dar University, Ethiopia.

14. Zeru G, Lijalem T (2016) Production and Reproduction Performances of Local Dairy Cattle: In the Case of Rural Community of Wolaita Zone, Southern Ethiopia. J Fisheries Livest Prod 4: 176.

15. Asaminew Tassew (2007) Production, handling, traditional processing practices and quality of milk in Bahir Dar milk shed Area, Ethiopia. M.Sc. Thesis. Alemaya University, Ethiopia.

16. Melku muluye (2016) Milk production and reproductive performance of local and crossbreed dairy cows in selected districts of west Gojam zone, Amhara region, Ethiopia. MSc. Thesis. Bahir Dar University, Ethiopia. p. 42-61.

17. Mulugeta Ayalew, Belayeneh Asefa (2013) Reproductive and lactation performances of dairy cows in Chacha Town and nearby selected kebeles, North Shoa Zone, Amhara Region, Ethiopia. World Journal of Agricultural Sciences 1(1): 008-017.

18. Beriso K, Tamir B, Feyera T (2015) Characterization of smallholder cattle milk production system in Aleta Chukko District, Southern Ethiopia. J Adv Dairy Res 3: 132.

19. Kedija H (2008) Characterization of milk production system and opportunity for market orientation: A Case Study of Mieso District, Oromia Region, Ethiopia. MScThesis submitted to Haramaya University, Ethiopia.

20. Tadesse M, Thiengtham J, Pinyopummin A, Prasanpanich S (2010) Productive and reproductive performance of Holstein Friesian dairy cows in Ethiopia. Livestock research for rural development 22: 2.

21. Sisay Eshetu (2015) Productive and reproductive performance of dairy cows (Horro, Horro X Friesian and Horro X Jersey) At Bako Agricultural Research Center. M.Sc Thesis, Haramaya University, Dire Dewa, Ethiopia.

22. Ansari Lari M, Mojtaba K, Mohammad S, Hasan N (2010) Reproductive performance of Holstein dairy cows in Iran. Trop Anim Health Prod 42: 1277-1283.

23. Chagas LM, Bass JJ, Blache D, Burke CR, Kay JK, et al. (2007) Invited review: New perspectives on the roles of nutrition and metabolic priorities in the sub fertility of high producing dairy cows. Journal of Dairy Science 90: 4022-4032.

24. Niraj Kumar, Yemane Abadi, Berihu Gebrekidan, Yohannes Hagos (2014) Productive and reproductive performance of local cows under farmer's management in and around Mekelle, Ethiopia. IOSR Journal of Agriculture and Veterinary Science (IOSR-JAVS) 7: 50-61.

25. Yaniz J, Lopez-Gatius F, Bech-sabat G, Garcia-Ispierto I, Serrano B, et al. (2008) Relationships between milk production, ovarian function and fertility in high-producing dairy herds in north-eastern Spain. Reproduction in Domestic Animals 4: 38-43.

26. Dobson H, Smith R, Royal M, Sheldon CK (2007) The high-producing dairy cow and its reproductive performance. Reproduction in Domestic Animals 2: 17-23.

27. Ali T, Lemma A, Yilma T (2015) Effect of management practices on reproductive performance of smallholder dairy cattle. Austin J Vet Sci and Anim Husb 2(3): 1015.

28. Assemu Tesfa, Dilip Kumar, Solomon Abegaz, Getinet Mekuriaw, Tewodross Bimerew, et al. (2016) Growth and reproductive performance of Fogera cattle breed at Andassa Livestock Research Center. Livestock Research for Rural Development 28: 1.
29. Getinet M, Workneh A, Hegde BP (2009) Growth and reproductive performance of Ogaden cattle at Haramaya University, Ethiopia. Ethiopian Journal of Animal Production (EJAP) 9(1): 13-38.

30. Tewodros Bimerew (2008) Assessment of productive and reproductive performance of indigenous and crossbred cattle under smallholder management system in North Gondar, Amhara Region. MSc. Thesis; Mekele University, Ethiopia pp. 136.

31. Dessalegn Genzebu, Berhan Tamir, Gebreyohannes Berhane (2016) Study of reproductive and production performance of cross breed dairy cattle under smallholder's management system in Bishoftu and Akaki Towns. Int J Adv Res. Biol Sci 3(2): 118-123.

32. Belay Duguma, Yisehak Kechero, Janssens GPJ (2012) Productive and Reproductive Performance of Zebu X Holstein-Friesian Crossbred Dairy Cows in Jimma Town, Oromia, Ethiopia. Global Veterinaria 8 (1): 67-72.

33. Tadele Alemayehu and Nibret Moges (2014) Study on reproductive performance of indigenous dairy cows at small Holder Farm Conditions in and Around Maksegnit Town. Global Veterinaria 13(4): 450-454.

34. Assemu Tesfa, Dilip Kumar, Solomon Abegaz, Getinet Mekuriaw (2016) Evaluations of Reproductive Performances of Fogera Cattle Breed in Selected Districts of Amhara Region, Ethiopia. International Journal of Pharma Medicine and Biological Sciences 5: 1.

35. FAO (2015) Measures of reproductive performance.

36. Habtamu L, Kelay B, Desie S (2010) Study on the reproductive performance of Jersey cows at Wolaita Sodo dairy farm. Southern Ethiopia, Ethiopia. Vet J 14 (1): 53-70.

37. Aynalem Haile, Workneh Ayalew, Noah Kebede, Tadelle Dessie, Azage Tegegne (2011) Breeding strategy to improve Ethiopian Boran cattle for meat and milk production. IPMS (Improving Productivity and Market Success) of Ethiopian Farmers Project Working Paper 26. Nairobi, Kenya, ILRI.

38. Almaz Bekele (2012) Genetic parameter estimation of growth and reproduction traits of Fogera cattle at Metekel ranch, Amhara region, Ethiopia. MSc Thesis submitted to Bahir Dar University college of Agriculture and environmental science, Bahir Dar, Ethiopia.

39. Melaku M, Zeleke M, Getinet M, Mengistie T (2011) Reproductive Performances of Fogera Cattle at Metekel Cattle Breeding and Multiplication Ranch, North West Ethiopia. J Anim Feed Res 1(3): 99106.

40. Mekonnen T, Bekana M, Abayneh T (2010) Reproductive performance and efficiency of artificial insemination smallholder dairy cows/heifers in and around Arsi-Negelle, Ethiopia. Livestock Research for Rural Development 22: 3.

41. Bindari-Raj Y, Sulochana S, Nabaraj S, Tara-Nath G (2013) Effects of nutrition on reproduction- A review. Advances in Applied Science Research. 4(1): 421-429.

42. Simenew K, Bekana M, Fikire L, Tilahun Z, Wondu M (2011) Major gross reproductive tract abnormalities in female cattle slaughtered at Sululta slaughterhouse in Ethiopia. Global Veterinaria 6(6): 506-513.

43. Berhanu Mekibib, Techan Desta, Dawit Tesfaye (2013) Gross pathological changes in the reproductive tracts of cows slaughtered at two abattoirs in Southern Ethiopia. Journal of Veterinary Medicine and Animal Health 5(2): 46-50.

44. Hagos Asgedom, Delesa Damena, Reta Duguma (2016) Seroprevalence of bovine brucellosis and associated risk factors in and around Alage district, Ethiopia. Springer Plus 5: 851.

45. Ararsa Duguma, Wubishet Zewdie (2014) Major reproductive health problems of indigenous Borena cows in Ethiopia. J Adv Vet Anim Res 1(4): 182-188. 
46. Molalegne Bitew, Prasad S (2011) Major reproductive health problems in indigenous and cross breed cows in and around Bedelle, South West Ethiopia. Journal of Animal and Veterinary Advances 10: 723-727.

47. Hadush A, Abdella A, Ragassa F (2013) Major Prepartu and postpartum Reproductive problems of dairy cattle in central Ethiopia. Journal of Veterinary Medicine and Animal Health 5: 118-123.

48. Bahlibi Weldegebriall (2015) Assessment of major reproductive problems of dairy cattle in selected sites of central zone of Tigray region, northern Ethiopia. MSc Thesis, Mekelle University, Ethiopia.

49. Gashaw A, Worku F, Mulugeta S (2011) Assessment of small holder dairy production system and their reproductive health problems in Jimma town South West Ethiopia. Jimma University College of Agriculture and Veterinary Medicine, Jimma, Ethiopia. International Journal of Research 9: 80- 86.

50. Abebaw Gashew, Frew Worku, Shiferaw Mulugeta (2011) Assessment of small holder dairy production system and their reproductive health production in Jimma town southwest Ethiopia. Intern J Appl Res Vet Med 9(1): 80-86.

51. Lorenz I Mee JF, Early B, More SJ (2011) Calf health from birth to weaning. I. General aspects of disease prevention. Irish Veterinary Journal 64: 10.

52. Adane Haile, Yisehak Tsegaye, Niguse Tesfaye (2014) Assessment of major reproductive disorders of dairy cattle in urban and per urban area of Hosanna, Southern Ethiopia. Animal and Veterinary Sciences 2: $135-141$

53. Tschopp R, Aseffa A, Zinsstag S (2014) Cattle productivity under traditional village husbandry system in Sellale, Central Ethiopia: A fourand-a-half-year herd follow-up. International Journal of Agriculture Innovations and Research 2: 2319-1473.

54. Asefa A, Ashenafi W (2016) Dairy calf morbidity and mortality and associated risk factors in Sodo town and its suburbs, Wolaita zone, Ethiopia. Slovak J Anim Sci 49(1): 44-56.

55. Sandeep RS, Ananda RK (2014) Effects of climate change on livestock production and mitigation strategies-review. International Journal of Innovative Research and Review 2(4): 124-144.

56. Thornton PK, Herrero M, Freeman A, Mwai E Rege O, Jones P et al. (2007) Vulnerability, climate change and livestock - research opportunities and challenges for poverty alleviation. International
Livestock Research Institute (ILRI), Nairobi, Kenya.

57. NMA (National Meteorological Agency) (2007) Climate change national adaptation program of action of Ethiopia, Abebe T Addis Ababa (Eds.), Ethiopia.

58. Abdeta A (2011) Effects of drought on cattle herd dynamics and its implication on local livelihood systems in Borana, Ethiopia. Food Security Center (FSC) Brief No 1: 1-6.

59. Bekele Megersa (2013) Climate change, cattle herd vulnerability and food insecurity: Adaptation through livestock diversification in the Borana pastoral system of Ethiopia. Institute of Animal Production in the Tropics and Subtropics, Dissertation Thesis. Stuttgart-Hohenheim.

60. IPCC (Intergovernmental Panel on Climate Change) (2007) Climate change: impacts, adaptation and vulnerability. Summary for policy makers.

61. Thornton PK, Gerber P (2010) Climate change and the growth of the livestock sector in developing countries. Mitigation Adaptation Strategy of Glob Change 15: 169-184.

62. Abdeta A, Oba G (2007) Relating long-term rainfall variability to cattle population dynamics in communal rangelands and a government ranch in southern Ethiopia. Agricultural Systems 94: 715-725.

63. Gebrekidan T, Zeleke M, Gangwar SK (2012) Reproductive and productive performance of dairy cattle in Central Zone of Tigray, Northern Ethiopia. I J ABR 2(1): 58-63.

64. Gizaw M, Bekana M, Abayneh T (2007) Major reproductive health problems in smallholder dairy production in and around Nazareth town, Central Ethiopia.

65. Haile A, Kassa T, Mihret M, Asfaw Y (2010) Major Reproductive Disorders in Crossbred Dairy Cows under Small holding in Addis Ababa Milkshed, Ethiopia. World Journal of Agricultural sciences 6: 412-418.

66. Melaku M, Zeleke M, Getinet M, Mengistie T (2011) Pre-weaning growth performances of Fogera calves at Metekel cattle improvement and multiplication ranch, North West Ethiopia. Livestock Research for Rural Development p. 23.

67. Yifat D, Bahilibi W, Desie S (2012) Reproductive performance of Boran cows at Tatesa cattle breeding center. Advances in Biol Res 6(3): 101105 .

\section{Your next submission with Juniper Publishers will reach you the below assets}

- Quality Editorial service

- Swift Peer Review

- Reprints availability

- E-prints Service

- Manuscript Podcast for convenient understanding

- Global attainment for your research

- Manuscript accessibility in different formats

( Pdf, E-pub, Full Text, Audio)

- Unceasing customer service

Track the below URL for one-step submission https://juniperpublishers.com/online-submission.php 